\title{
Kesiapan dan Keberhasilan Pemerintah Daerah dalam Rangka Reformasi Akuntansi dan Penerapan PP No. 71 Tahun 2010: Berdasarkan Tinjauan Literatur
}

\author{
Angelina Putu Winda Savira' ${ }^{1)}$, Indrawati Yuhertina ${ }^{2)}$ \\ 1), 2) Universitas Pembangunan Nasional "Veteran", Jawa Timur \\ Email:17013010238@student.upnjatim.ac.id
}

\begin{abstract}
Accounting reform in Indonesia, the government has made many changes in the financial sector, namely by means of three packages of laws that have become the basis for the management of state finances for a decade. Then the government issued another PP. 71 of 2010 which talks about financial accounting standards or what is often called SAP. Change is not easy to implement quickly and requires good preparation and understanding before it can be implemented so that the government can produce transparent, quality and accountable financial reports. By using a literature review, this study aims to see what factors influence the readiness and application of this new government accounting system. Human resources, supporting tools, and organizational commitment have a positive effect and have a major role in the application of accrual-based government accounting standards, although they still have limited understanding and readiness.
\end{abstract}

Keywords: Readiness, success, implementation, government accounting standards, accounting reforms, accrual-based accounting, governance, PP. 71 of 2010

\begin{abstract}
Abstrak
Reformasi akuntansi di Indonesia yaitu pemerintah melakukan banyak perubahan di bidang keuangan dengan memunculkan tiga paket Undang-undang yang telah menjadi dasar pengelolaan keuangan negara sudah mencapai satu dekade. Kemudian pemerintah mengeluarkan Kembali PP No. 71 Tahun 2010 yang mengatur mengenai standar akuntansi keuangan pemerintahan atau yang sering disebut SAP. Perubahan ini tidak mudah dilaksanakan secara cepat, butuh persiapan dan pemahaman yang baik sebelum dapat mengimplementasikan agar pemerintah dapat menghasilkan laporan keuangan yang transparan, berkualitas, dan akuntabel. Dengan menggunakan pendekatan tinjauan literatur, penelitian ini bertujuan untuk mengetahui apa saja faktor yang mempengaruhi kesiapan dan keberhasilan penerapan sistem akuntansi pemerintahan yang baru ini. Sumber daya manusia, perangkat pendukung, serta komitmen organisasi dinyatakan berpengaruh positif dan memiliki peranan besar terhadap penerapan standar akuntansi pemerintahan akuntansi berbasis akrual walaupun masih memiliki keterbatasan pemahaman maupun kesiapan.
\end{abstract}

Kata Kunci: Kesiapan, Keberhasilan, Implementasi, Standar akuntansi pemerintah, Reformasi akuntansi, Akuntansi berbasis akrual, Pemerintahan, PP No. 71 Tahun 2010

\section{Pendahuluan}

Reformasi akuntansi yang terjadi di Indonesia tidak terasa sudah mencapai satu dekade lebih. Reformasi adalah sebuah perubahan signifikan terhadap kegiatan atau sistem yang sebelumnya belum pernah terjadi suatu perubahan sama sekali. Oleh karena itu, reformasi akuntansi harus dilakukan dengan tujuan meningkatkan dan mengejar ketinggalan kualitas pelayanan publik yang dirasa masih jauh dari kata memadai. Pada era reformasi, pemerintah Indonesia berupaya keras meningkatkan kualitas dari pelayanan publik. Pemerintah melakukan banyak sekali perubahan-perubahan fundamental khususnya pada bidang keuangan negara yang dibuktikan dengan munculnya tiga paket Undang-undang yang sekarang menjadi dasar pengelolaan keuangan negara dan mengacu pada international best 
practices (Norfaliza, 2015).

Ketiga paket Undang-undang tersebut adalah Undang-undang Nomor 17 Tahun 2003 Tentang Keuangan Negara, Undang-undang Nomor 1 Tahun 2004 Tentang Pembendaharaan Negara, dan Undang-undang Nomor 15 Tahun 2004 Tentang Pemeriksaan Pengelolaan dan Tanggung Jawab Keuangan Negara. Pada tanggal 22 Oktober 2010, pemerintah menerbitkan Peraturan Pemerintah Nomor 71 Tahun 2010 Tentang Standar Akuntansi Pemerintahan atau disingkat dengan SAP. PP Nomor 71 Tahun 2010 merupakan Standar Akuntansi Pemerintahan berbasis akrual yang mengakui asset, pendapatan, utang, beban dan ekuitas ke dalam pelaporan finansial berbasis akrual. Selain itu, standar akuntansi pemerintahan ini mengakui pendapatan, pembiayaan, dan belanja dalam pelaporan pelaksanaan anggaran berdasarkan dari basis yang ditetapkan APBN/APBD.

Standar akuntansi pemerintahan berbasis akrual ini tentu saja tidak mudah untuk diterapkan. Beberapa pihak mungkin akan mengalami permasalahan-permasalahan dalam mengimplementasikan standar akuntansi pemerintahan ini. Arih et al., (2017) mengatakan penerapan standar akuntansi pemerintahan berbasis akrual adalah sebuah proses yang berkesinambungan, memiliki dampak yang tidak dapat dilihat dalam waktu singkat, yang menyebabkan pemahaman mengenai faktor apa saja yang mempengaruhi keberhasilan ataupun kegagalan yang terjadi dipenerapan sistem akuntansi yang baru. (Fuad, 2013), menambahkan penerapan akuntansi akrual di pemerintahan masih sangat rendah dan berada pada level 33,3\%. Oleh karena itu, diperlukan analisis, perencanaan yang matang dan pemahaman yang baik terkait dengan beberapa sistem baru serta apa saja faktor-faktor yang mempengaruhi penerapan standar akuntansi pemerintahan berbasis akrual.

Diperlukannya persiapan yang baik untuk mengimplementasikan standar akuntansi pemerintahan ini karena basis akrual dibutuhkan agar pemerintah dapat menghasilkan laporan keuangan yang transparan, berkualitas, dan akuntabel. Banyak sekali faktor yang mempengaruhi dari penerapan standar akuntansi pemerintahan berbasis akrual dan faktorfaktor ini sangat mempengaruhi tingkat keberhasilan pemerintah dalam menerapkan standar akuntansi pemerintahan berbasis akrual. Pada beberapa sumber penelitian sebelumnya, adanya informasi menunjukkan bahwa kualitas sumber daya manusia (SDM), komitmen organisasi, dan perangkat pendukung menjadi faktor yang banyak dikatakan peneliti sebagai faktor-faktor yang mempengaruhi penerapan standar akuntansi pemerintahan berbasis akrual.

Penelitian yang dilakukan oleh Widyastuti et al., (2015), Langelo et al., (2015), Kristiawati, (2015), Sari et al., (2017) dan Abdurrahim et al., (2019) menyatakan bahwa kualitas sumber daya manusia berpengaruh positif terhadap kesiapan dan keberhasilan pemerintah menerapkan standar akuntansi pemerintahan berbasis akrual tetapi dengan hasil yang rendah. Arih et al., (2017) juga memperkuat dengan menyatakan bahwa kualitas sumber daya manusia berpengaruh signifikan dengan arah yang positif kepada penerapan standar akuntansi pemerintahan berbasis akrual. Pada penelitian sebelumnya, menyatakan bahwa komitmen organisasi memiliki peranan penting untuk penerapan standar akuntansi pemerintahan berbasis akrual. Norfaliza, (2015) mengatakan komitmen organisasi berpengaruh terhadap kesiapan pemerintah menerapkan standar akuntansi pemerintahan berbasis akrual. Dari hasil penelitian sebelumnya dikatakan bahwa organisasi sepakat untuk menerapkan standar akuntansi pemerintahan berbasis akrual tetapi, masih kurangnya komitmen organisasi. Kristiawati, (2015) mengatakan kurangnya komitmen dari atasan yang menyebabkan perlu dilakukannya trik dan inisiatif masing-masing pribadi untuk menggali informasi mengenai akuntansi akrual. 
Simanjuntak, (2010) mengatakan bahwa sebuah dukungan besar dari seorang pimpinan dan kerjasama bersama pegawai adalah sebuah kunci dari keberhasilan suatu perubahan. Dikatakan oleh Putra \& Ariyanto, (2015) pengaruh positif dari gaya kepemimpinan terhadap kesiapan dan keberhasilan penerapan standar akuntansi pemerintahan berbasis akrual yang dilakukan diorganisasi tersebut. Tetapi faktor ini masih sangat rendah didalam pengimplementasian standar akuntansi pemerintahan berbasis akrual. Pada penelitian yang dilakukan oleh Kristiawati, (2015), Abdurrahim et al., (2019), Norfaliza, (2015), Ramli et al., (2020) mengatakan bahwa perangkat pendukung serta adanya pelatihan yang relevan merupakan sebuah faktor yang saling melengkapi dan simultan terhadap keberhasilan penerapan standar akuntansi pemerintahan berbasis akrual. Walaupun perangkat pendukung merupakan faktor yang penting dalam keberhasilan penerapan standar akuntansi pemerintahan berbasis akrual, faktor ini diteliti masih sangat rendah termasuk belum maksimalnya pelatihan yang relevan sehingga tidak memudahkan sumber daya manusia untuk bekerja.

Penelitian ini spesifik mengupas apa saja faktor-faktor yang mempengaruhi kesiapan dan keberhasilan pemerintah dalam menerapkan standar akuntansi pemerintahan berbasis akrual sesuai dengan Peraturan Pemerintah Nomor 71 Tahun 2010 Tentang Standar Akuntansi Pemerintahan. Dari penelitian-penelitian sebelumnya dijelaskan bahwa faktor yang mempengaruhi kualitas, kesiapan, dan keberhasilan penerapan SAP adalah sumber daya manusia (SDM), komitmen organisasi, gaya kepemimpinan dan perangkat pendukung. Dengan demikian jelas bahwa faktor-faktor ini akan menjadi pusat perhatian peneliti untuk membahas pengaruhnya terhadap penerapan standar akuntansi pemerintahan berbasis akrual.

\section{TINJAUAN PUSTAKA}

\subsection{Pemerintah Daerah}

Menurut Undang-Undang No. 23 Tahun 2014 Tentang Pemerintahan Daerah Pada Bab 1 Pasal 1 dikatakan bahwa pemerintah daerah adalah penyelenggaraan urusan pemerintahan oleh pemerintah daerah dan dewan perwakilan rakyat daerah menurut asas otonomi dan tugas pembantuan dengan prinsip otonomi seluas-luasnya dalam sistem dan prinsip Negara Kesatuan Republik Indonesia sebagaimana dimaksud dalam Undang-Undang Dasar Negara Republik Indonesia Tahun 1945. Pemerintah Daerah adalah kepala daerah sebagai unsur penyelenggara Pemerintahan Daerah yang memimpin pelaksanaan urusan pemerintahan yang menjadi kewenangan daerah otonomi.

\subsection{Kebijakan Akuntansi Pemerintah}

Menurut Undang-Undang No. 17 Tahun 2003 (dalam Herwiyanti et al., 2017) menteri keuangan adalah sebagai pelaksana kekuasaan atas pengelolaan fiskal selain itu memiliki tugas menyusun laporan keuangan yang merupakan pertanggungjawaban dari pelaksanaan APBN. Kemudian Kebijakan Akuntansi Pemerintah Pusat yang telah ditetapkan oleh Peraturan Menteri Keuangan Republik Indonesia Nomor 219 Tahun 2013 adalah turunan dari standar akuntansi pemerintahan dan pelaporan pada pemerintahan pusat dalam penyusunan laporan keuangan.

Pada Peraturan Menteri Keuangan Republik Indonesia Tentang Kebijakan Akuntansi Pemerintah Pusat Pasal 3, Kebijakan Akuntansi Pemerintah Pusat bertujuan untuk:

a. Memberikan pedoman bagi Entitas Akuntansi dan Entitas Pelaporan pada pemerintah pusat dalam menyusun Laporan Keuangan Pemerintah Pusat, Laporan Keuangan 
Bendahara Umum Negara, dan Laporan Keuangan Kementerian Negara Lembaga dalam rangka meningkatkan keterbandingan Laporan Keuangan baik antar periode maupun antar Entitas Pelaporan; dan

b. Memberikan pedoman dalam pelaksanaan sistem dan prosedur akuntansi pemerintah pusat.

\subsection{StandarAkuntansi Pemerintahan Berbasis Akrual}

Menurut Peraturan Pemerintah No. 71 Tahun 2010 Tentang Pemerintahan Daerah Pada Bab 1 Pasal 1 Ayat (3) dikatakan Standar Akuntansi Pemerintahan, yang selanjutnya disingkat SAP, adalah prinsip-prinsip akuntansi yang diterapkan dalam menyusun dan menyajikan laporan keuangan pemerintah. Selanjutnya pada Ayat (8) SAP Berbasis Akrual adalah SAP yang mengakui pendapatan, beban, aset, utang, dan ekuitas dalam pelaporan financial berbasis akrual, serta mengakui pendapatan, belanja, dan pembiayaan dalam pelaporan pelaksanaan anggaran berdasarkan basis yang ditetapkan dalam APBN/APBD.

Dikatakan pada Bab III Pasal 9 Ayat (1) bahwa Peraturan Pemerintah Nomor 24 Tahun 2005 tentang Standar Akuntansi Pemerintahan (Lembaran Negara Republik Indonesia Tahun 2005 Nomor 49, Tambahan Lembaran Negara Republik Indonesia Nomor 4503) dicabut dan dinyatakan tidak berlaku; dan (2) Peraturan perundang-undangan yang mengatur mengenai penyelenggaraan akuntansi pemerintahan sepanjang belum diubah dan tidak bertentangan dengan Peraturan Pemerintah ini, dinyatakan tetap berlaku. Peraturan pemerintah ini sudah harus diterapkan pada tiap laporan keuangan pemerintah daerah paling lambat tahun 2015 .

Pada Hasanah \& Fauzi, (2008), komponen laporan keuangan pemerintah daerah yang telah berbasis akrual adalah sebagai berikut:

- Laporan Realisasi Anggaran (LRA)

- Laporan Perubahan Saldo Anggaran Lebih (LSAL)

- Neraca

- Laporan Arus kas

- Laporan Operasional (LO)

- Laporan Perubahan Ekuitas

- Catatan Atas Laporan Keuangan

\subsection{Kesiapan dan Keberhasilan Pemerintah Daerah}

Menurut (Kristiawati. 2015), jika pemerintah ingin menunjang keberhasilan penerapan SAP berbasis akrual, maka pemerintah seharusnya melakukan pembenahan diri. Pembenahan diri yang dimaksudkan adalah dalam segi Sumber Daya Manusia, maupun hal lainnya yang berkaitan dengan kesiapan dan keberhasilan dari penerapan SAP berbasis akrual. Menurut Wiryaningsih et al., (2017), sebuah keberhasilan dari organisasi dalam mencapai tujuantujuannya akan dicerminkan dari masing-masing individu dalam melaksanakan tugas yang telah diamanatkan oleh atasannya. Keberhasilan dari perubahan standar akuntansi berbasis akrual pada pemerintahan, tentu akan menghasilkan laporan keuangan yang lebih transparan dan akuntabel hal ini dikatakan memerlukan upaya serta kerja sama dari banyak pihak.

\section{Metode Penelitian}

Penelitian ini menggunakan pendekatan tinjauan literatur dalam mengumpulkan data-data 
dari penelitian terdahulu menggunakan jurnal yang didapatkan melalui data base Google Cendekia dengan menggunakan kata kunci "kesiapan pemerintah" dan "PP No. 71 Tahun 2010" dengan rentang waktu dari tahun 2015 sampai dengan 2020, muncul sebanyak 202 jurnal. Selanjutnya, masih dengan rentang waktu yang sama tetapi mengganti kata kunci menjadi "kesiapan pemerintah" dan "reformasi akuntansi" memunculkan sebanyak 33 hasil. Kata kunci "kesiapan pemerintah" dan "standar akuntansi pemerintah" dengan rentang waktu yang sama, memunculkan 263 hasil. Kata kunci "kesiapan" dan "implementasi standar akuntansi pemerintah" dengan rentang waktu yang sama memunculkan 65 hasil. Setelah mencari data menggunakan kata kunci tersebut melalui Google Cendekia, penulis melakukan scanning dan mendapatkan 25 jurnal berkompeten yang tepat dengan penelitian ini dan digunakan sebagai sumber utama data yang akan dianalisis.

Tabel 1. Jenis Penelitian

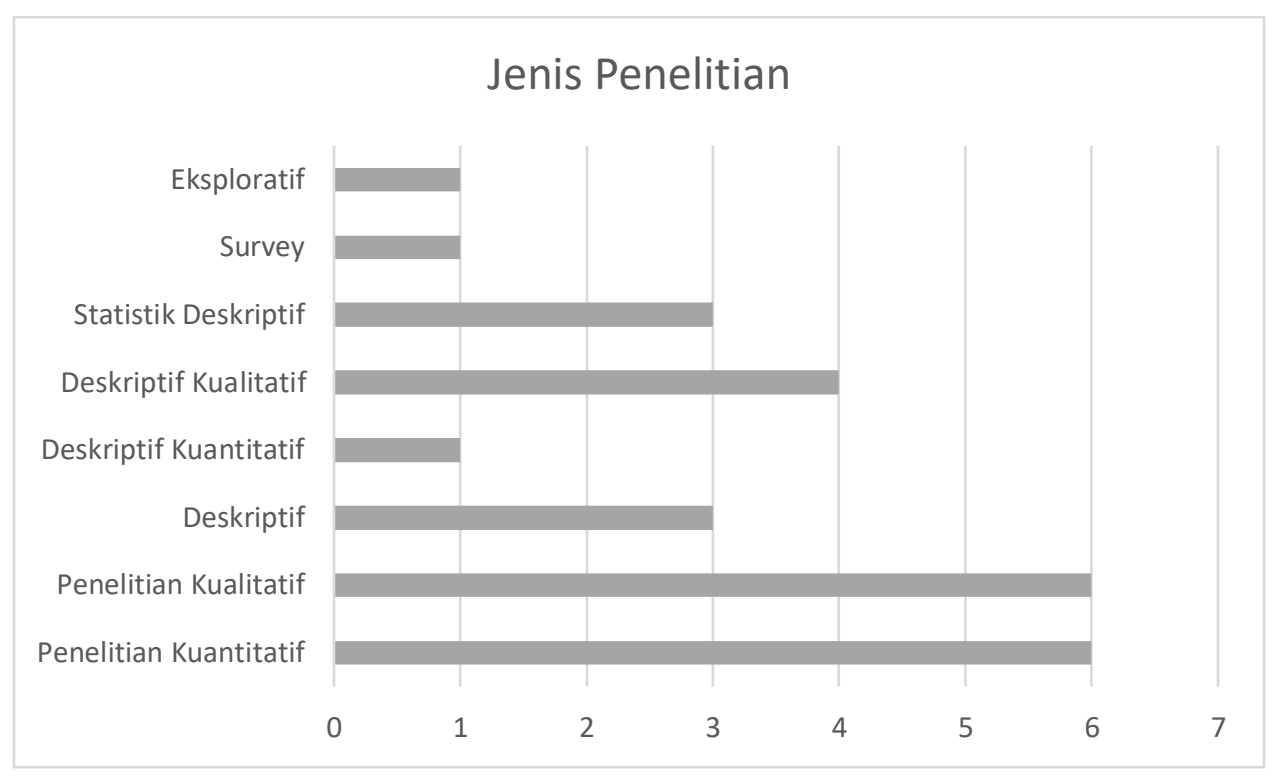

Sumber: DiolahPeneliti

Melalui pengumpulan jurnal dan yang akan dijadikan sebagai tinjauan literatur, maka dilakukan pembahasan, menganalisa dan melakukan review penelitan sebelumnya dan mengumpulkan pendapat dari para ahli, yang berkaitan dengan kesiapan dan keberhasilan pemerintah daerah. Penulis memilih pendekatan ini karena memungkinkan untuk penelitian dilakukan secara terstruktur, lebih jelas dan dapat direplikasi. Selain itu, menurut Snyder, (2019) pendekatan ini lebih mengutamakan ketelitian didalam proses penelitian.

Jenis data yang digunakan dalam penelitian ini adalah data sekunder dengan metode yang digunakan dalam penelitian ini adalah metode kualitatif. Sebuah metode yang menurut Mattoasi, (2019) penelitian kualitatif dapat menggunakan lebih dari satu jenis data untuk menghasilkan sebuah data penelitan. Setelah melakukan analisa terhadap jurnal-jurnal yang dijadikan sebagai tinjauan literatur, peneliti menemukan bahwa jenis data yang digunakan sangat beragam walaupun didominasi oleh data primer. Penelitian yang menggunakan data beragam diharapkan dapat menghasilkan penelitian yang lebih baik lagi serta lebih dalam kepada suatu fenomena. 
Tabel 2. Jenis Data

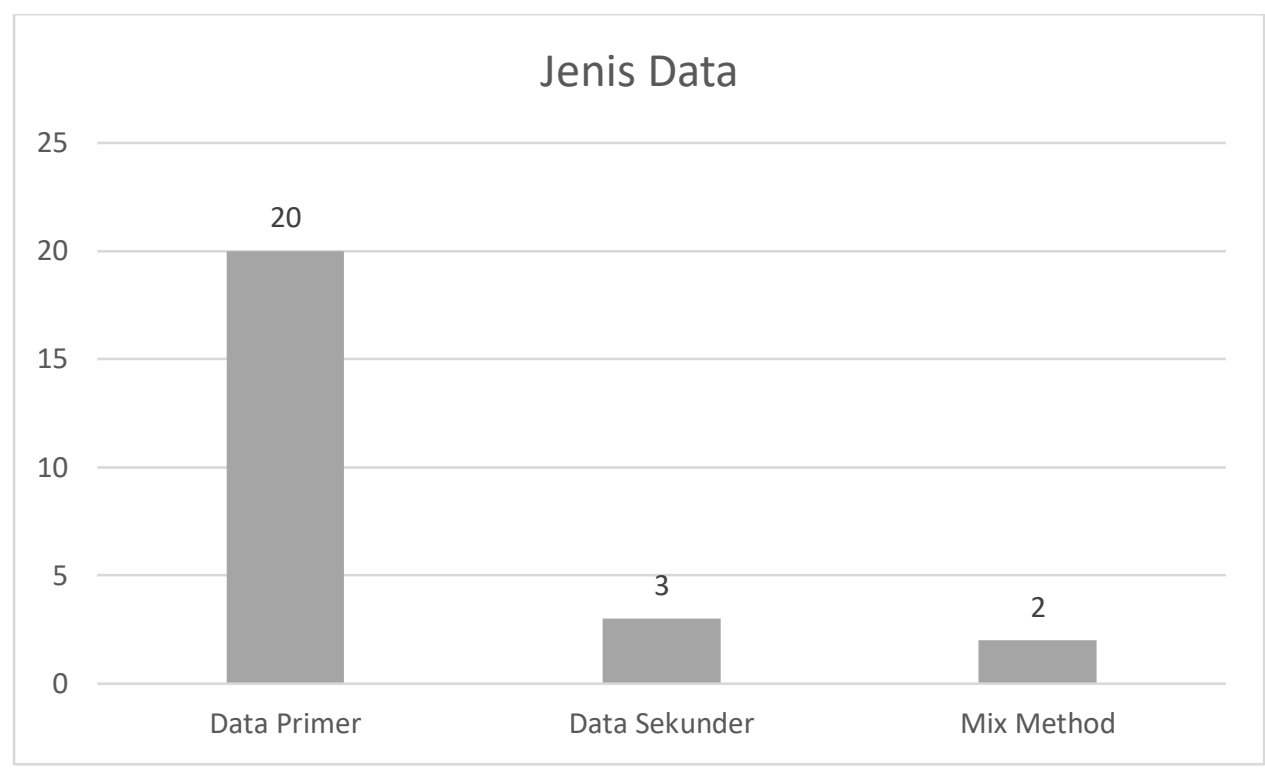

Sumber: Diolah Peneliti

\section{Hasil dan Pembahasan}

Menurut hasil pembahasan dari penelitian sebelumnya pada tujuh provinsi, delapan kota, dan sepuluh kabupaten, memiliki variabel yang beragam tetapi secara keseluruhan memiliki beberapa kesamaan. Dengan beragamnya variabel dari penelitian sebelumnya, membantu peneliti menemukan hal-hal baru mengenai faktor apa saja yang mempengaruhi kesiapan dan keberhasilan pemerintah dalam menerapkan SAP berbasis akrual. Ini juga menjadi sebuah tolak ukur dalam menganalisa apa saja yang sebenarnya perlu disiapkan pemerintah daerah. Pada tabel 3 akan dijabarkan variabel-variabel yang menjadi pembahasan pada penelitian sebelumnya.

\subsection{Kesiapan dan Keberhasilan}

Sumber daya manusia, sistem informasi dan komitmen organisasi menjadi variabel yang paling banyak dianalisa oleh peneliti terdahulu. Hal ini akan lebih dibahas pada sub bab setelah ini. Pelatihan merupakan penunjang keberhasilan dari pemerintah daerah dalam menerapkan SAP berbasis akrual. Hal ini menjadi penting karena berkesinambungan dengan ketidaksiapan dari sumber daya manusia. Selain itu, regulasi sebagai pedoman dari kebijakan SAP berbasis akrual, peran sarana prasarana dalam kesiapan perangkat sistem informasi, serta komunikasi yang baik di SPKD menjadi unsur-unsur penting dalam keberhasilan pemerintah daerah menerapkan SAP berbasis akrual. Pada tabel 3 akan dijabarkan variabel-variabel pendukung menurut penelitian terdahulu. 
Tabel 3. Variabel

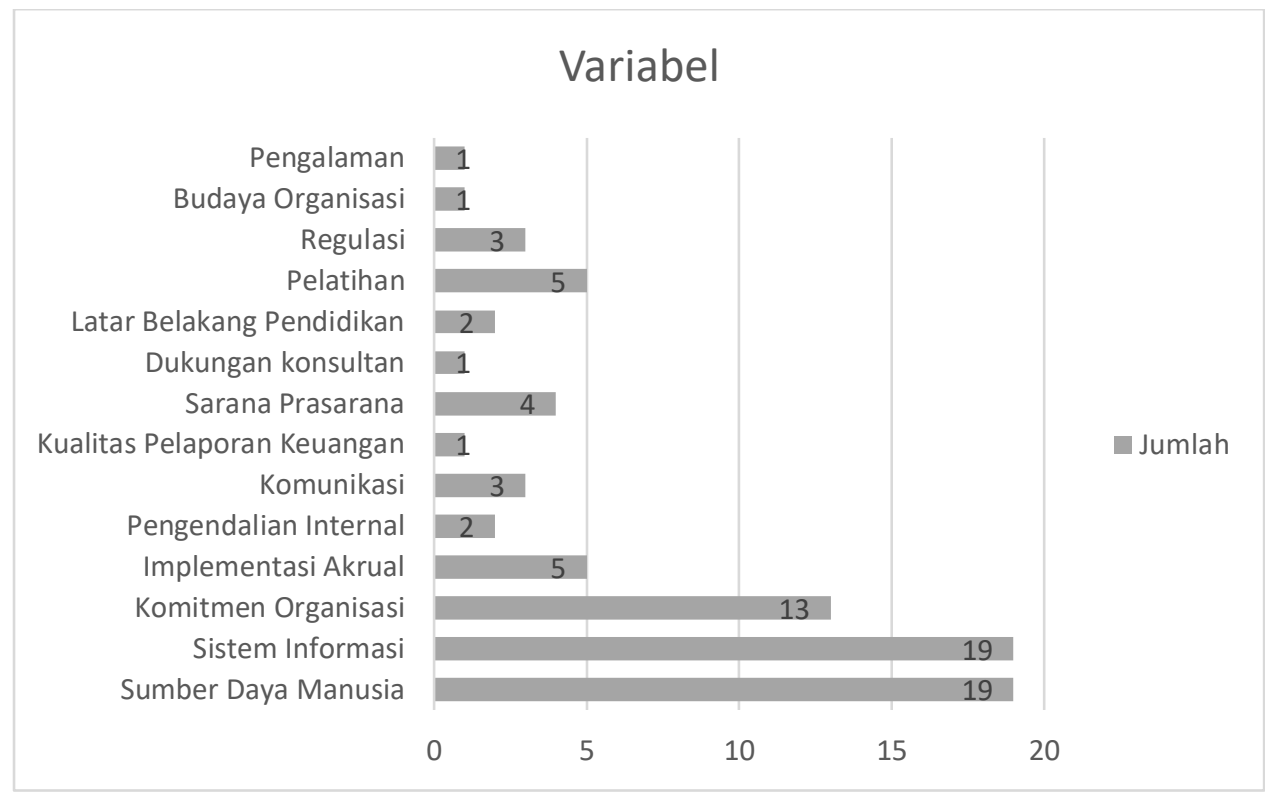

Sumber: DiolahPeneliti

Pada tahun pertama pada saat sektor publik melakukan transisi perubahan standar, beberapa daerah belum siap dalam menerapkan SAP berbasis akrual. Dengan adanya beberapa daerah yang tidak siap, maka hal ini berdampak pada keberhasilan pemerintah daerah dalam menerapkan PP No. 71 Tahun 2010. Namun selama berjalannya waktu, peningkatan dari kesiapan di daerah tertentu dapat terlihat sehingga tentu meningkatkan kemungkinan dari keberhasilan penerapan SAP berbasis akrual.

\subsection{Pemahaman dan Penerapan Akuntansi Basis Akrual}

Dalam penerapan akuntansi berbasis akrual yang dapat dikatakan tergolong baru, setiap individu baik yang memiliki latar belakang akuntan atau tidak, tetap memerlukan pemahaman yang baik untuk dapat menjalankan SAP berbasis akrual. Demi tercapainya cita-cita pemerintah untuk menjadikan laporan keuangan lebih berkualitas, efisien dan efektif, tentunya diperlukan kesiapan yang matang dalam segi pemahaman agar dapat menerapkan basis akrual sesuai standar.

Pemahaman yang dimiliki oleh setiap individu pada penelitian sebelumnya dikatakan masih sangat terbatas dan kurang memahami bagaimana konsep serta sistem akuntansi berbasis akrual. Dibuktikan dengan penelitian (Kristiawati, 2015), menyatakan bahwa pemahaman karyawan publik tentang akuntansi berbasis akrual masih sangat minim sehingga diperlukannya pelatihan teknis khususnya untuk PP No. 71 Tahun 2010 sangat dibutuhkan terlebih pada tiap SPKD yang kesulitan memahami. Hal ini perlu diperhatikan karena dasar dalam keberhasilan menerapkan SAP berbasis akrual yang baru ini adalah dapat memahami terlebih dahulu bagaimana konsepnya jika masih banyak sumber daya manusia yang tetap 
tidak memahami konsep dan sistem maka tujuan utama pemerintah dalam memajukan kualitas laporan keuangan dapat terhambat dan lebih parahnya tidak mengalami kemajuan.

\subsection{Kesiapan Sumber Daya Manusia dalam penerapan Standar Akuntansi Pemerintah Berbasis Akrual}

Sumber daya manusia selalu menjadi yang utama untuk diteliti disetiap penelitian terdahulu. Menurut Satrio et al., (2016), sumber daya manusia yang professional serta berkompeten dalam mengelola keuangan daerah adalah hal utama yang dibutuhkan oleh tiap instansi untuk menjalankan sistem, program, dan ikut menyukseskan tujuan pemerintah dalam penerapan akuntansi berbasis akrual di laporan keuangan pemerintah. Menurut Norfaliza, (2015) Sumber daya manusia mempengaruhi nilai kesiapan pemerintah dalam menerapkan SAP berbasis akrual, yang berarti jika sumber daya manusia dikelola dengan baik, maka dapat menghasilkan sumber daya manusia yang berkualitas dan berkompeten sehingga penerapan dan pembuatan laporan keuangan yang berdasarkan SAP berbasis akrual dapat berjalan dengan baik dan lancar.

Faktanya pada setiap penelitian terdahulu, sumber daya manusia dikatakan belum sepenuhnya siap dalam menerapkan SAP berbasis akrual. Banyak faktor yang mempengaruhi hal ini. Beberapa faktor yang mempengaruhi ketidaksiapan sumber daya manusia adalah latar belakang pendidikan SDM yang bukan dari ekonomi atau profesinya bukan seorang akuntan. Selain itu, belum dilaksanakan pelatihan dan persiapan SDM mengenai sistem akuntansi berbasis akrual dan belum adanya inisiatif dari SDM dalam mempelajari dan memahami akuntansi berbasis akrual khususnya PP No. 71 Tahun 2010.

\subsection{Kesiapan Perangkat Pendukung Dalam Penerapan Akuntansi Berbasis Akrual}

Perangkat pendukung atau yang sering disebut dengan sistem informasi akuntansi, terbukti memiliki peran penting dalam keberhasilan SAP berbasis akrual ini dikarenakan telah adanya kemajuan teknologi di Indonesia. Tentu kemajuan teknologi memiliki peranan penting dalam mempermudah kegiatan manusia. Salah satunya adalah memudahakan pegawai dalam menerapkan SAP berbasis akrual dengan sistem infromasi akuntansi yang ada.

Menurut penelitian terdahulu, sudah tersedianya perangkat pendukung pada setiap instansi daerah. Perangkat pendukung ini berupa sistem informasi Manajemen Daerah (SIMDA) pada computer dan dari segi IT sistem informasi akuntansi telah menyiapkan software dan hardware yang mendukung SAP berbasis akrual khususnya PP No. 71 tahun 2010. Setiap instansi daerah sudah dengan baik menyiapkan perangkat pendukung yang mempengaruhi keberhasilan dari penerapan SAP berbasis akrual.

Walaupun perangkat daerah sudah dengan baik diberikan fasilitas pada setiap komputer, sangat disayangkan bahwa sumber daya manusia yang ada pada setiap instansi dikatakan belum memahami cara penggunaan perangkat pendukung SIMDA dengan maksimal. Para pegawai instansi banyak yang mengalami kebingungan berhubungan dengan cara penggunaan perangkat pendukung ini. Ini sangat disayangkan mengingat sebagus dan sesiap apapun perangkat pendukungnya, jika sumber daya manusia tidak memadai untuk mengoperasikannya maka keberhasilan dalam menerapkan SAP berbasis akrual tidak akan mengalami kemajuan. Maka dari itu, diperlukannya pelatihan bagi setiap sumber daya manusia agar dapat dengan maksimal menjalankan perangkat pendukung SIMDA yang telah disiapkan.

\subsection{Komitmen Organisasi Dalam Penerapan Sistem Akuntansi Berbasis Akrual}


Menurut Wiryaningsih et al., (2017) komitmen organisasi adalah sebuah sikap dari pegawai yang memiliki ketertarikan terhadap tujuan, nilai, dan sasaran organisasi hal ini ditunjukkan dengan adanya penerimaan antar individu mengenai nilai serta tujuan organisasi dan memiliki sebuah keinginan untuk berhubungan dengan dengan organisasi serta bekerja untuk organisasi dan menjadikan hal tersebut motivasi pegawai untuk tetap bertahan pada sebuah organisasi demi tercapainya tujuan serta keberlangsungan organisasi.

Menurut Satrio et al., (2016) komitmen juga menjadi salah satu faktor yang berpengaruh besar dan dikatakan terpenting terhadap kesiapan serta keberhasilan pemerintah daerah dalam penerapan SAP berbasis akrual. Dengan komitmen dari pimpinan, maka kebijakan-kebijakan dapat dilaksanakan dan dijadikan pedoman dalam tiap kegiatan. Penelitian yang dilakukan oleh (Widyastuti et al., 2015) dan Wiryaningsih et al., (2017), mengatakan instansi daerah, pemimpin atasan, dan para pegawai telah melakukan komitmen dalam rangka mendukung SAP berbasis akrual. Komitmen yang dilakukan bertujuan untuk melakukan perubahan kearah yang lebih baik dan membangun kepercayaan masyarakat terhadap hasil kinerja pemerintah daerah.

Komitmen yang dilakukan telah menjadi awal yang baik untuk menerapkan SAP berbasis akrual kedepannya. Namun tetap harus dilakukan banyak komitmen dalam pelatihan untuk memajukan sumber daya manusia. Peranan atasan dalam berkomitmen untuk melakukan pelatihan konsep, sistem dan teknis kepada pegawai sangat dibutuhkan pada setiap instansi daerah yang baru menerapkan SAP berbasis akrual ini.

\section{Kesimpulan}

Banyak faktor yang mempengaruhi kesiapan serta keberhasilan pemerintah dalam menerapkan PP No. 71 tahun 2010 tentang standar akuntansi pemerintah berbasis akrual. Beberapa faktor tersebut adalah sumber daya manusia, perangkat pendukung, serta komitmen organisasi. Dari ketiga faktor tersebut, semuanya berpengaruh positif terdahap kesiapan penerapan SAP berbasis akrual dapat dibuktikan dari ketiga faktor tersebut saling berpengaruh satu sama lain. Selain itu masih banyak faktor lain yang mempengaruhi kesiapan dan keberhasilan pemerintah daerah dalam menerapkan SAP berbasis akrual.

Penelitian sebelumnya mengatakan bahwa sumber daya manusia menjadi yang sangat berpengaruh terhadap kesiapan penerapan akuntansi berbasis akrual. Tetapi masih minimnya pemahaman SDM mengenai konsep, sistem dan teknis penerapan akuntansi berbasis akrual, menyebabkan ketidaksiapan dalam penerapannya. Hal ini juga dipengaruhi oleh latar belakang pendidikan dan kurangnya pemberian pelatihan kepada SDM.

Sumber daya manusia juga mempengaruhi kesiapan perangkat pendukung yang ada pada tiap instansi. Sarana prasarana dan perangkat pendukung berupa SIMDA baik software maupun hardware telah dipasangkan kepada masing-masing komputer pegawai. Tetapi kembali lagi masih kurangnya pemahaman dari para pegawai mengenai cara mengoperasikan SIMDA, sehingga perangkat pendukung yang telah siap bisa dikatakan bekerja kurang maksimal.

Komitmen organisasi sebenarnya dapat menjadi sebuah jawaban dalam permasalahan ini. Adanya komitmen dari pemimpin atasan dan pegawai untuk memperbaruhi sumber daya manusia agar dapat mencapai tujuan pemerintah yaitu memperbaiki kualitas dari laporan keuangan sangat diperlukan mengingat SDM memiliki peran besar dalam keberhasilan reformasi dibidang keuangan yang bisa dibilang baru saja terjadi.

\section{Daftar Pustaka}


Abdurrahim, Hidayati, D. N., \& Budiarto. (2019). Implementasi Peraturan Pemerintah Nomor 71 Tahun 2010 Tentang Standar Akuntansi Pemerintahan Berbasis Akrual (Studi Pada Pemerintah Kabupaten Lombok Barat). Jurnal Ilmiah, 16(1), 99-110.

Arih, T. N., Rahayu, S., \& Nurbaiti, A. (2017). Plementasi Standar Akuntansi "Pemerintahan" Analisa Faktor-Faktor Yang Mempengaruhi Berbasis Akrual Pada Pemerintah Kota Bandung. Jurnal Manajemen Indonesia,17(1), 67-78.

Fuad, M. I. Y. K. (2013). Analisis Faktor-faktor yang Mempengaruhi Tingkat Penerapan Akuntansi Akrual pada Pemerintah. Diponegoro Journal of Accounting, 2(3).

Hasanah, N., \& Fauzi, A. (2008). Akuntansi Pemerintahan.

Herwiyanti, E., Sukirman, S., \& Sufi Aziz, F. (2017). Analisis Implementasi Akuntansi Berbasis Akrual pada Inspektorat Jenderal Kementerian Keuangan. Jurnal Akuntansi Dan Keuangan, 19(1), 13-23. https://doi.org/10.9744/jak.19.1.13-23

Kristiawati, E. (2015a). Faktor-Faktor Yang Mempengaruhi Keberhasilan Penerapan Akuntansi Berbasis Akrual Pada Pemerintahan Daerah Kalimantan Barat. Jurnal Riset Inspirasi Manajemen Dan Kewirausahaan, 8(3), 171-190. https://doi.org/10.35130/jrimk.v3i2.68

Kristiawati, E. (2015b). Faktor-Faktor Yang Mempengaruhi Keberhasilan Penerapan Akuntansi Berbasis Akrual Pada Pemerintahan Daerah Kalimantan Barat. Akuntabilitas, 8(3), 171-190. https://doi.org/10.35130/jrimk.v3i2.68

Langelo, F., Saerang, D. P. E., \& Alexander, S. W. (2015). Analisis Penerapan Standar Akuntansi Pemerintahan Berbasis Akrual Dalam Penyajian Laporan Keuangan Pada Pemerintah Kota Bitung. Jurnal EMBA, 3(1), 1-8.

Mattoasi. (2019). Efektivitas Penggunaan Media Vibermixo Dalam Meningkatkan Motivasi Belajar Siswa Pada Mata Kuliah Akuntansi: Berdasarkan Tinjauan Literatur. Economic Education Journal, 1(1), 35-43.

Norfaliza. (2015). Analisis Faktor Kesiapan Pemerintah Dalam Menerapkan Akuntansi Pemerintah Berbasis Akrual (Studi Kasus Pada Skpd Kabupaten Rokan Hilir). Jom FEKON, 2(2), 1-14.

Peraturan Menteri Keuangan Republik Indonesia No. 225/PMK.05/2019 Kebijakan Akuntansi Pemerintah Pusat.31 Desember 2019. Lembaran Negara Republik Indonesia Tahun 2019. Jakarta.

Peraturan Pemerintah Republik Indonesia Nomor 71 Tahun 2010 Standar Akuntansi Pemerintahan. 22 Oktober 2010. Lembaran Negara Republik Indonesia Tahun 2010. Jakarta.

Putra, I. W. G. Y. D., \& Ariyanto, D. (2015). Faktor-faktor yang Mempengaruhi Penerapan Standar Akuntansi Pemerintahan Berbasis Akrual. E-Jurnal Akuntansi Universitas Udayana, 13(1), 14-32.

Ramli, M., Afriwan, O., \& Budiarto. (2020). Keberhasilan Implementasi Peraturan Pemerintah Nomor 71 Tahun 2010 Tentang Standar Akuntansi Pemerintahan Berbasis Akrual. Jurnal Unmasmataram, 14(1), 406-412. https://doi.org/10.35327/gara.v14i1.114

Sari, Y. P., Hetika, \& Mahmudah, N. (2017). Evaluasi Penerapan Sistem Akuntansi Akrual: 
Studi Kasus Di Badan Layanan Umum Daerah Rsud Kardinah Kota Tegal. Jurnal AKSI (Akuntansi Dan Sistem Informasi), 1(1), 18-28. https://doi.org/10.32486/aksi.v1i1.92

Satrio, M. D., Yuhertiana, I., \& Hamzah, A. (2016). Implementasi Standar Akuntansi Pemerintah Berbasis Akrual di Kabupaten Jombang. Jurnal Akuntansi Dan Keuangan, 18(1), 59-70. https://doi.org/10.9744/jak.18.1.59-70

Simanjuntak, B. H. (2010). Penerapan Akuntansi Berbasis Akrual di Sektor Pemerintahan Indonesia. Presented at the Congress XI Institute of Indonesia Chartered Accountants (Ikatan Akuntan Indonesia/IAI). (unpublished).

Snyder, A. (2019). Literature review as a research methodology: An overview and guidelines. J. Bus. Res., 104, 333-339.

Undang-Undang Republik Indonesia Nomor 23 Tahun 2014 Pemerintah Daerah.30 September 2014. Lembaran Negara Republik Indonesia Tahun 2014. Jakarta.

Widyastuti, N. M. A., Sujana, E., \& Adiputra, I. M. P. (2015). Analisis Kesiapan Pemerintah Daerah Dalam Menerapkan Standar Akuntansi Pemerintahan Berbasis Akrual Di Kabupaten Gianyar. E-Journal SI Ak Universitas Pendidikan Ganesha, 3(1).

Wiryaningsih, N. N. D., Sulindawati, N. L. G. E., \& Prayudi, M. A. (2017). Analisis Penerapan Peraturan Pemerintah Nomor 71 Tahun 2010 Tentang Standar Akuntansi Pemerintah Berbasis Akrual Pada Rumah Sakit Umum Kabupaten Bangli. E-Journal S1 Ak Universitas Pendidikan Ganesha, 8(2). 